
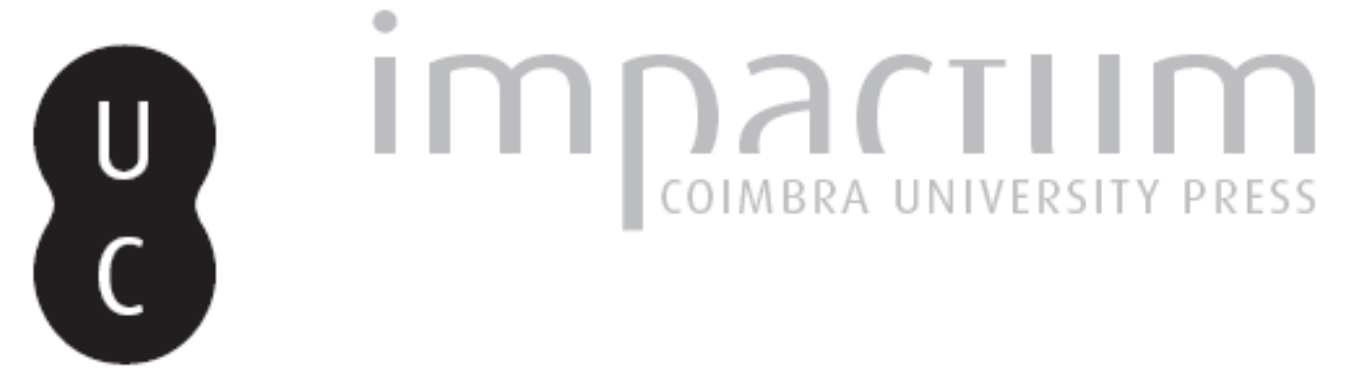

\title{
Em busca do contexto do último escrito filosófico de Antero
}

Autor(es): Serrão, Joel

Publicado por: Imprensa da Universidade de Coimbra

URL persistente:

URI:http://hdl.handle.net/10316.2/43740

DOI:

DOI:https://doi.org/10.14195/2183-8925_13_3

Accessed : $\quad$ 26-Apr-2023 10:58:40

A navegação consulta e descarregamento dos títulos inseridos nas Bibliotecas Digitais UC Digitalis, UC Pombalina e UC Impactum, pressupõem a aceitação plena e sem reservas dos Termos e Condições de Uso destas Bibliotecas Digitais, disponíveis em https://digitalis.uc.pt/pt-pt/termos.

Conforme exposto nos referidos Termos e Condições de Uso, o descarregamento de títulos de acesso restrito requer uma licença válida de autorização devendo o utilizador aceder ao(s) documento(s) a partir de um endereço de IP da instituição detentora da supramencionada licença.

Ao utilizador é apenas permitido o descarregamento para uso pessoal, pelo que o emprego do(s) título(s) descarregado(s) para outro fim, designadamente comercial, carece de autorização do respetivo autor ou editor da obra.

Na medida em que todas as obras da UC Digitalis se encontram protegidas pelo Código do Direito de Autor e Direitos Conexos e demais legislação aplicável, toda a cópia, parcial ou total, deste documento, nos casos em que é legalmente admitida, deverá conter ou fazer-se acompanhar por este aviso.

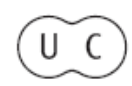


REVISTA DE HISTÓRIA DAS IDEIAS 13

\section{Antero de Quental}

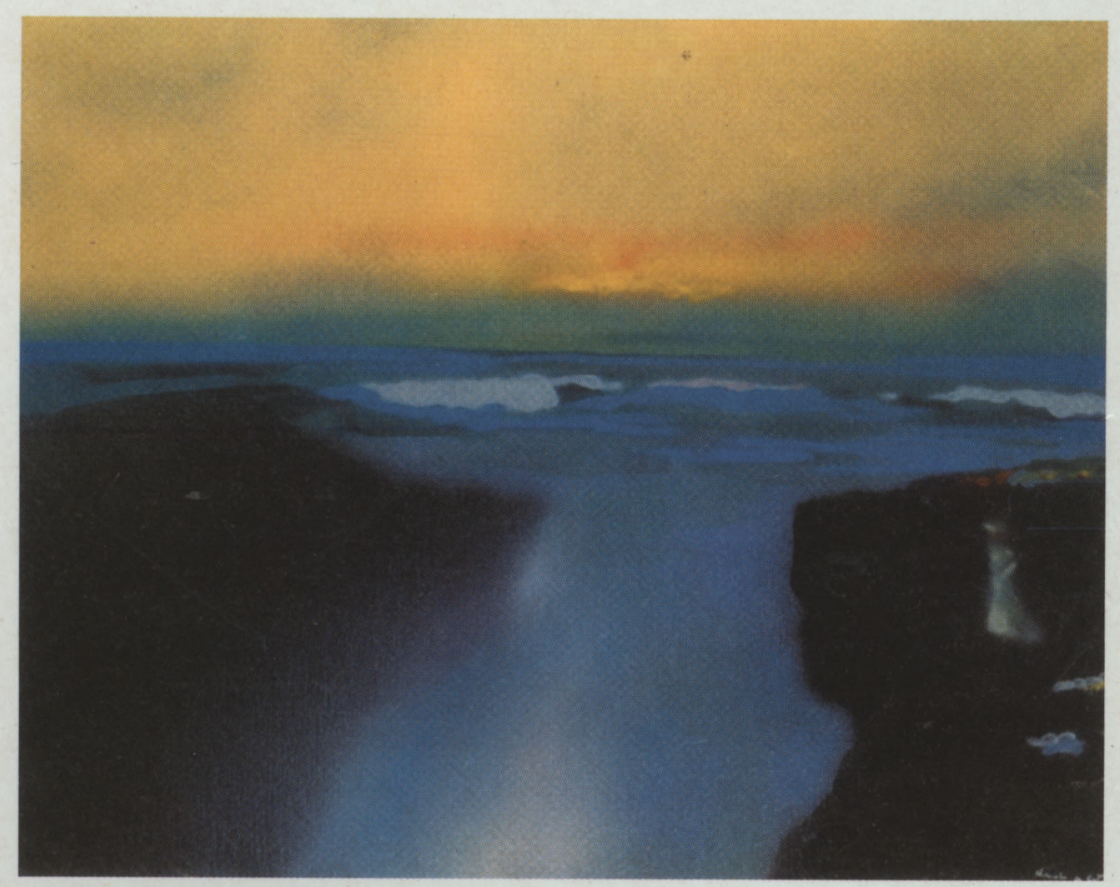

INSTITUTO DE HISTÓRIA E TEORIA DAS IDEIAS FACULDADE DE LETRAS

COIMBRA 1991 


\title{
EM BUSCA DO CONTEXTO DO ÚLTIMO ESCRITO FILOSÓFICO DE ANTERO
}

\author{
O SER-exprime a união \\ do sujeito e do objecto.
}

Hölderlin

Em carta a Alberto Sampaio, datável dos começos de 1889 (Março?), Antero confidencia ao antigo e dilecto amigo: "Eu cá estou [em Vila do Conde] entregue aos meus estudos e pensamentos filosóficos, ainda que às vezes chego a desanimar, principalmente quando, como agora, aumentam as minhas complicações ou perturbações nervosas e com elas uma certa confusão intelectual e desgoto das coisas. Receio ter-me metido numa empresa muito superior às minhas forças e fico aterrado diante da consideração da minha enorme ignorância! Só agora é que vejo quanto tempo perdi. Mas isso agora é irremediável" (').

Pelos fins desse mesmo ano [Dezembro?], e após estadias em Lisboa, no Cartaxo, e na Praia da Granja [Agosto], as quais totalizaram três meses de ausência do seu poiso habitual, informava Oliveira Martins: "(...) desde que para aqui [Vila do Conde] voltei [Setembro?]

* Faculdade de Ciências Sociais e Humanas da Universidade Nova de Lisboa.

(') Antero de Quental, Cartas II (1881-1891). Organização, introdução e notas de Ana Maria Almeida Martins, Lisboa, 1989, p. 931. Itálicos nossos. 
tenho estado ocupado a escrever, ocupação que, quando para aí me dá, me absorve e sobretudo, depois da tarefa diária, me faz aborrecer papel e pena. Para mostrar o meu afecto ao nosso [Eça de] Queirós, comecei a escrever, com destino à Revista [de Portugal], um artigo sobre as tendências gerais da Filosofia na actualidade, coisa sumária: mas o assunto apossou-se de mim, passou a ser quase outra coisa o trabalho e no fim de três meses acho-me tendo produzido um estudo [itálico nosso] que na Revista dará 3 ou 4 artigos, e que depois ampliado será um livro. Ficou reservada muita coisa que naturalmente não cabe em artigos de Revista. Escuso dizer-lhe que não é a minha filosofia, aquela que $V$. sabe que eu tenho, com o seu método próprio e teorias particulares. Essa, infelizmente, desisto de a expor porque está acima das minhas forças o fazê-lo - e depois ninguém me entenderia. Mas, em suma, são as minhas ideias, somente expostas por um método impessoal, pondo de parte as minhas vistas originais e processo próprio dialéctico, e apresentadas simplesmente como induzidas da evolução do pensamento moderno e mais especialmente das tendências filosóficas dos últimos 80 anos. [Itálicos nossos] De sorte que, amigo, ainda depois de publicar um livro de filosofia, ficarei sempre um filósofo inédito. Espero que V. encontre no meu estudo algumas páginas que lhe agradem. Em todo o caso, peço-lhe que o leia com atenção, para me indicar lacunas, contradições e o mais que parecer bem ser reformado, esclarecido ou desenvolvido, para a forma definitiva do livro. [Itálicos nossos] Os artigos começarão a sair em Fevereiro, provavelmente. Estou agora passando a limpo. [Itálico nosso] Esta ocupaçãotem-me feito bem, de sorte que talvez continue, considerando sobretudo que é o único lado por onde posso ser prestável. V.é homem de acção, e o terramoto que se aproxima [o conflito com a Inglaterra] abre-lhe horizontes e promete-lhe um teatro digno da sua actividade. A mim não me repugna a aç̧ão, pelo contrário, creio até que é o que está no fundo do meu temperamento, mas acção muito outra e tal que hoje não tem lugar, nem ocasião para se exercer. No século XVI teria sido homem de acção, ou com os homens da espada ou com os da cruz; noutros séculos também, doutros modos. Mas hoje sinto-me como fora do meu meio natural e a minha retraç̧ão é ao mesmo tempo instintiva e reflectiva. Quando a gente chega aos 48 anos tem obrigação de saber para que serve e para que não, e não ir atrás de fantasias. A verdade é que, para o que há a fazer e se pode fazer na sociedade actual, sou duma 
absoluta inabilidade, um verdadeiro incapaz. Se alguma influência posso exercer sobre os homens é só de longe e pela ideia pura. Compreendo bem que V., sentindo-se tão isolado, anseie por um companheiro e o que me diz na sua carta sobre a necessidade de $e u$ voltar à superfície exprime bem esse sentimento. E eu sê-lo-ia - com que vontade e gosto, escuso dizê-lo - esse seu companheiro de luta, se me não conhecesse completamente incapaz para aquilo de que se trata. Tenho pois de me conservar no meu papel, quero dizer na lógica do meu carácter e das minhas aptidões. (...) De resto, quem sabe o que virá? Não recusarei diante de coisa alguma, senão só daquilo que repugnar a lógica e harmonia do meu ser. 'The right man in the right place"' (2).

Por Dezembro do mesmo ano de 1889, testemunha em carta para Joaquim de Araújo: "(...) passo bem e tenho podido continuar a trabalhar nos meus artigos filosóficos, que começarão a publicar-se em Fevereiro, segundo penso, pois já estão concluídos e estou-os agora passando a limpo" ( $\left.{ }^{3}\right)$.

No ano seguinte, 1890, em 1 de Fevereiro, informa José da Cunha Sampaio: "O próximo número da Revista de Portugal trará um artigo filosófico meu, $10^{\circ}$ duma série de 3 , que irão a seguir. Conto depois ampliar aquilo e fazer dali um livrinho. [Itálicos nossos] Peço pois ao Alberto [Sampaio] que os leia com atenção e tome nota de quaisquer lacunas, erros, obscuridades, etc., com o que me ajudará e concorrerá para que o escrito definito fique menos imperfeito" $\left({ }^{4}\right)$. [Itálicos nossos]

Por Março desse mesmo ano, depois de uma "justificação" da sua acção na "Liga Patriótica do Norte", resultado do Ultimatum inglês (11 de Janeiro), confessa a Alberto Sampaio ter ficado contente com "a impressão que te causou o meu $1 .^{\circ}$ artigo da Revista. Oxalá te agradem igualmente os outros 2 . Em todo o caso, aquilonão passará a livro sem muitas correç̧ões, além dos desenvolvimentos que the hei-de dar na parte histórica, que por ora foi só indicada." [Itálicos nossos] $\left(^{5}\right)$.

\footnotetext{
(2) Idem, ibidem, pp. 966-967.

(3) Idem, ibidem, p. 974. Itálico nosso.

(4) Idem, ibidem, p. 979.

(5) Idem, ibidem, p. 987.
} 
Nos termos do que, em síntese, se logrou apurar afigura-se legítimo explicitar os seguintes pontos de referência no que toca à redacção de "Tendências gerais da filosofia na segunda metade do século XIX".

1) Nos começos de 1889, Antero estava empenhado em "estudos e pensamentos filosoficos" oque, aliás, nesta fase final da sua caminhada, provinha, pelo menos, de $1885-1886$, tal como no capítulo II deste estudo se mostrará.

2) Tendo Eça de Queirós se lançado à direcção da Revista de Portugal, a qual se publicou a partir de Julho de 1889, é certo que Antero logo terá sido convidado a colaborar nela como se infere da carta a Oliveira Martins de fins de 1889. Simplesmente, "um artigo, coisa sumária" transformara-se num "estudo" desdobrável em 3 ou 4 artigos, o qual, por seu turno, fora entrevisto como virtual embrião de um "livro" que, como é sabido, jamais se efectivaria.

3) Concluída a tarefa destinada à Revista de Portugal, Antero entendeu por bem rever e copiar o estudo, dando-lhe a sua forma definitiva, o que logrou levar a efeito, pelo menos, ate à página 82 do manuscrito, o qual se encontra em vias de publicação.

4) Entretanto, o agravamento das dissensões anglo-portuguesas relativamente à disputa de terras africanas culminaria no Ultimatum britânico de 11 de Janeiro de 1890 o qual, por seu turno, suscitaria uma complexa agitação nacional e nacionalista da qual foi parte a constituição no Porto da Liga Patriótica do Norte, cuja presidência Antero viria a aceitar em 6 de Fevereiro.

5) Tais factos em si mesmos e pela agitação que lhe terão suscitado impedem-no de continuar a tarefa de prosseguir a cópia e a revisão do original que havia escrito, a qual só é feita até parte da página 82, como se verifica no original. Com efeito, a partir daí, a caligrafia modifica-se e a numeração das páginas, em vez de à direita, é feita sempre à esquerda.

6) Que é possível induzir, com prudência, destes factos?

Em face das referências disponíveis, não se entrevê outra explicação além desta: o manuscrito da p. 79 à 134 que, eventualmente, depois de trabalhado, poderia ter dado os, hipoteticamente, previstos 4 capítulos (ou artigos), é integrado, tal qual fora redigido, como conclusão do estudo, cujos capítulos I e II haviam sido entregues e estavam em vias de publicação.

E daí, - interroga-se - as diferenças notadas por qualquer leitor 
atento das "Tendências" entre o tom e o ritmo dos dois primeiros capítulos e do terceiro e último? $\left(^{6}\right)$.

É bem sabido que jamais fora fácil a Antero a determinação de um rumo adequado às suas complexas e interconexas inquietações $\left(^{7}\right)$. Recorrendo ora à via poética ora à reflexão filosófica ou para-filosofica (₹), lá foi navegando como ia sabendo e podendo, numa dada sorte de complexa auto-aprendizagem da sageza que lhe fora sendo viável.

Noperíodo de 1871 a 1875 , concebera e, com enorme afã, procurara levar por diante um Programa para os Trabalhos da Geração Nova, o qual soçobrou devido às dificuldades de ordem filosófica que não lograra equacionar $\left({ }^{9}\right)$. E o mesmo iria a acontecer a uma Teoria da Religião que, intermitentemente, o ocupou de 1876 a 1878.

(') Por exemplo, António Sérgio em Notas sobre os "Sonetos" e as Tendências Gerais da Filosofia de Antero de Quental, Lisboa, 1909, considera: "Quem lê os dois primeiros capítulos das Tendências gerais da filosofia na segunda metade do século $X I X$, sente-se arrastado por uma certa fluidez vaga, onde é difícil encontrar uma sequência lógica precisa, apesar da clareza aparente devida à sua prosa tão bela, ainda que talvez muito igualmente iluminada.

Depois de atacar, na segunda parte, as grandes construções especulativas e os seus 'mitos' em nome das 'ciências modernas', da 'observação', da 'adaptação aos factos', da 'indução cautelosa' Antero na terceira levanta repentinamente um palácio de ideias escandalosamente aéreo e poético, ressuscitando a 'pretensão exorbitante' que pouco antes atacara: terramoto de cenário, que num ponto se refaz. 'Nada há mais fácil, disse Schopenhauer, nem mais inútil, do que refutar um filósofo'. Se refutar um filósofo pode ser obra vã, é certamente mau gosto, se não barbaridade, refutar um poeta; não é pois o que pretendemos, nem o que pretenderíamos, se nos achássemos capazes de o fazer. 'Os sistemas são os sistemas, etc.'. Nãoé só isso: quando se não tem muito método, rigor científico, espírito crítico e objectivo, é infalível que sejam precisamente os sentimentos quem governe nos sistemas - os quais ficam assim, da mesma forma, a exprimir 'a pessoa toda inteira'".

$\left(^{7}\right)$ V. de nossa autoria, "Antero à procura de ocupação para a sua alma" in $O$ Primeiro Fradique Mendes, Lisboa, 1985, pp. 13-94.

( $\left.{ }^{8}\right)$ V. Antero de Quental, Obras Completas III Filosofia. Organização, introdução e notas de Joel Serrão, Lisboa, 1991, tex tos "A Bíblia da Humanidade de Michelet", "O sentimento da imortalidade", "Arte e Verdade - I Carácter positivo da arte", "Espontaneidade" e "O futuro da música" e respectivas anotações.

(') V., da nossa autoria, Antero e a Ruína do seu "Programa" (1871/1875), Lisboa, 1988. 
Entretanto, instalado, a partir de 1881, em Vila do Conde, ali escreve, em 1885, o seu último soneto, o qual e os anteriores seriam dados a lume, no ano seguinte, sob o título de Sonetos Completos.

Encerrando, como que "oficialmente", a sua caminhada poética, dir-se-ia que Antero, enfim, psicologicamente, se auto-dispunha a entregar-se de todo à reflexão filosófica $\left({ }^{10}\right)$. E, com efeito, é isso que levaria por diante até à redacção de "Tendências gerais da filosofia na segunda metade do século XIX", escrito dado a lume nos primeiros meses de 1890.

Claro está: quem conheça seu tanto da complexae sinuosa caminhada poético-filosófica de Antero sabe ou vai aprendendo que as coisas não ocorreram com essa excessiva simplicidade. E daí que importe lembrar ou relembrar dadas confidências do poeta em vias de se transformar, ai dele!, "exclusivamente" em filósofo.

Em 28 de Março de 1885, esse ano charneira, - se na sua vida os há -, confidencia ao seu conterrâneo e amigo Francisco Machado de Faria e Maia: "Vivo aqui [Vila do Conde], numa terrazinha morta onde não conheço ninguém, com duas crianças que também não conhecem ninguém, além de mim. Esta singularidade de vida não é uma extravagância, mas em parte necessidade imposta pelas condições da doença, em parte como sistema por mim adoptado, para ver se chego a um equilíbrio moral, indispensável para qualquer espécie de trabalho. Se por este sistema me não curar, então nunca me curo. De resto, tenho um tal sossego interior, que posso dizer que sou feliz, no bom e único verdadeiro sentido da palavra. É um fruto da Filosofia, e quem me diria a mim, quando em Coimbra comecei a cultivá-la, que o que então era para mim só curiosidade da inteligência, viria a ser agora amparo moral, fonte de energia e escudo contra mil e um males! [Itálico nosso] Mas - quem a boa árvore se chega, boa sombra o cobre - diz o rifão $e$ não sou eu o primeiro, vai já em três mil anos, para quem a Filosofia, começando pela inteligência, acaba por entrar no coração, apossando-se dele e da vida toda, como de coisa sua. [Itálicos nossos] Não penses, porém, por isto, que acabei em reduzir, como os estóicos dos últimos tempos romanos, toda a Filosofia à moral, com a preocupação exclusiva da direcção da vida. Continuo pois especulando, e tenho lido

$\left({ }^{10}\right)$ V., da nossa autoria, "Da poesia à filosofia" in Antero de Quental, "Hino da Manhã" e outras Poesias do mesmo Ciclo, Lisboa, 1989, pp. 27-34. 
e pensado bastante, possuindo hoje um conjunto definido de ideias, como quem diz, o meu sistema. [Itálicos nossos]

Oxaláque ainda possa encontrar-me contigoe com o vagar suficiente para te expor o dito sistema, a ti que és um dos poucos cá na nossa terra que entendem de tais coisas. Dir-me-ás que o escreva, e é o que todos me dizem; mas a todos respondo que não posso; porque para isso é necessário que as minhas faculdades voltem ao antigo equilíbrio, condição indispensável de um tal trabalho. Mas quem sabe se readquirirei jamais esse ditoso equilíbrio? Entretanto, como não desespero, continuo a definir e ordenar cada vez melhor as minhas ideias, e não considero que seja este tempo perdido. Veremos o que daqui por uns anos poderei fazer. [Itálico nosso] E, a propósito destas coisas, quero dizer-te que acabei por chegar a ideias semelhantes ou paralelas às tuas, quanto à Monadologia. Lembras-te das conversas que tivemos há anos em Lisboa, a tal respeito? Pois hoje entendo que a ideia de Substância, implicando as do Absoluto, Unidade, Simplicidade, Continuidade, etc., é a última ou mais remota das ideias metafisicas, indispensável para a explicaçãofinal do Ser, mas incapaz de explicar imediatamente a realidade, o descontínuo, o complexo, etc. [Itálicos nossos]: que são vãos por isso todos os Panteísmos, e que é indispensável ligá-la (e é essa a missão da Monadologia) por meio da ideia de Força, com a realidade, isto é, com o Atomismo. Em vez pois de partir da Substância, para chegar dedutivamente ao mundo físico, uma Filosofia realista deverá proceder inversamente; partirá dos dados elementares da sensibilidade, sobre que se baseiam em última análise as ciências naturais, isto é, dos Átomos, para indutivamente chegar ao que não é Átomo, mas que o Átomo pressupõe: a Substância. Numa palavra, é necessário vazar toda a metafísica dentro do Átomo, e depois então trabalhar com ele, assim transformado. Não posso desenvolver isto; mas para ti, esta simples indicação bastará para que aprecies o ponto de vista em que estou hoje. Quanto às conclusões morais a que por um tal caminho cheguei, já pelos meus Sonetos (digo alguns deles) pudeste fazer alguma ideia.

O que deles me dizes, causou-me satisfação, pois, como aquilo é só para poucos e tu és desses, o teu voto não podia deixar de me agradar muito. Entretanto, o meu pensamento ainda ali se mostra obscuro e perturbado por outros elementos, sobretudo pelo pessimismo. [Itálico nosso] Tenho, porém depois daquela data, composto uns quinze ou 
vinte, onde o fundo do meu pensar e sentir se revela nítido e puro, e onde cheguei a dar expressão poética (e creio que ninguém ainda $o$ tinha feito) ao misticismo moderno, misticismo científico e positivo, se assim se pode dizer." [Itálico nosso] $\left({ }^{11}\right)$.

Em 7 de Agosto desse mesmo ano de 1885, em carta a Carolina Michaëlis de Vasconcelos, Antero refere-se à próxima publicação dos seus Sonetos Completos sobre os quais tece considerações de muito interesse e explica a transição da poesia para a filosofia tal a experiencia: "Nos mesmos poetas, era o fundo mais que a forma que me atraía. Mas, na minha impaciência, na minha impetuosidade, saltava dali e a linguagem abstrusa, o formalismo, a extraordinária abstracção de Hegel não me assustavam nem repeliam; pelo contrário, internava-me com audácia aventureira pelos meandros e sombras daquela floresta formidável de ideias, como um cavaleiro andante por alguma selva encantada à procura do grande segredo, do grande fétiche, do Santo Graal, que para mim era a Verdade, a verdade pura, estreme, absoluta... Era uma grande ilusão, como todos os Santos Graais: mas essa ilusão me levou gradualmente da imagem para o pensamento, fez-me sondar o que toda a alta poesia pressupõe, mas esconde tanto quanto revela, e para quê encobrir esta minha velha e inveterada pretensão? - fez de mim um Filósofo. [Itálico nosso] Um filósofo manqué, talvez porque, afinal, ainda não revelei ao mundo o meu Apocalipse, nem sei se chegarei a revelá-lo... Mas, em todo o caso, pretensão ou realidade, 0 certo é que o filósofo, que por muito tempo só se exprimiu pela boca do poeta, acabou por confiscar, por absorver, por devorar o pobre poeta, e agora que este acabou, impõe-se ao filósofo (para não passar por um assassino gratuito e aleivoso) a obrigação de ser gente por si só e de falar pela própria boca. A colecção dos meus Sonetos é o testamento do pobre poeta que acabou. Entro agora numa fase nova, e tenho jurado consagrar-me daqui em diante, todo e exclusivamente, ao trabalho de coordenação definitiva das minhas ideias filosóficas e, se tanto puder, à exposição metódica e rigorosa das mesmas. [Itálico nosso] ${ }^{(2)}$.

Alguns meses após, pelos fins de 1885, confidencia: " (...) não me

(1) Antero de Quental, Cartas II (1881-1891), ob. cit., pp. 729-730.

(12) Idem, ibidem, p. 748. 
pesa este isolamento, que, sem o Lobo de Moura, seria total, porque estou sempre entretido, tendo conseguido uma certa disciplina no estudo, coisa bem difícil em sujeito tal como eu, mas queéindispensável para poder com método, ordem e sossego de espírito entregar-me à minha grande obra. [Itálicos nossos] Não posso ficar indefinidamente filosofo inédito e preciso justificar a reputação que amigos tal vez menos discretos me fizeram. Entretanto, enquanto não domaros nervos e a imaginação, e não tiver transformado o meu antigo temperamento de poeta no de filósofo, não posso começar a grande obra." [Itálico nosso] $\left({ }^{13}\right)$.

Ainda nesse mesmo ano, na véspera de Natal, em carta para Jaime Batalha Reis insiste no processo em curso da transformação do poeta em filósofo, lamenta que Oliveira Martins tenha tratado "com pouco respeito" as "minhas ideias filosóficas e religiosas" e explica qual é, ao seu olhar, a problemática filosófica com que se debate.

"Extrair do pessimismo o optimismo, por um processo racional, tem sido afinal o trabalho da minha vida. Creio que cheguei ao termo e dou a minha Filosofia por completa e acabada. [Itálico nosso] Agora trata-se de a expor lucidamente, e é a isso que me quero consagrar, tendo porém de vencer ainda preliminarmente a resistência dos meus nervos e mau feitio de cabeça, operação melindrosa e longa. A dita minha Filosofia não é original. É antes uma fusão (não amálgama) do Hegelianismo com a monadologia do Leibniz, dando de si a sintese do idealismo e do espiritualismo num terreno que à $1 .{ }^{a}$ vista se parece com o materialismo. [Itálico nosso] Digo que se parece porque o meu ponto de partida é com efeito o materialismo, ou atomismo científico. Mas, reduzindo a ideia de átomo à de força, e esta à de espírito, e transportando para o átomo-mónada toda a espontaneidade $e$ virtualidade que o Hegel atribui à ideia, [Itálico nosso] consigo reconduzir o Idealismo e o Espiritualismo da região vaga e abstracta por onde tem andado para um terreno quanto é possível nestas coisas, positivo. O que há de original no meu trabalho são apenas 3 coisas: 1. - uma teoria do conhecimento, que é o preliminar lógico do meu sistema: $22^{\circ}$ a análise da ideia de matéria, a que acabei de me referir: 3. $a$ análise da ideia de Absoluto, que reduzo à de Liberdade, transportando-a da esfera da inteligência para a da consciência.

$\left({ }^{13}\right)$ Idem, ibidem, p. 757. 
[Itálicos nossos] Estes três pontos, porém, sendo fundamentais, servem-me de critério e são por assim dizer o grude com que ligo umas às outras muitas teorias que são mais ou menos do domínio comum da filosofia moderna. $O$ meu sistema está numa linha paralela ao do Hartmann [Karl-Robert-Eduard von Hartmann (1842-1906)], distinguindo-se dele no método e numa maior dose de realismo, e parecendo-se com ele nas tendências gerais e nas conclusões morais. [Itálicos nossos] Chegámos a um tempo (como foi na Antiguidade o da escola de Alexandria) em que já não pode haver filosofias originais. $O$ que se deve pedir a um sistemaé só que, sendo uno e consistente traduza e dê expressão racional às tendências contemporâneas do espírito humano. O meu sistema será pois (como todos, nofundo) um ensaio de interpretação do Universo no ponto de vista do espírito moderno, interpretado esse mesmo espírito pela razão crítica [Itálico nosso]. Se conseguir fazer isto satisfatoriamente, não darei por vão o meu esforço" $\left({ }^{14}\right)$.

Logo em Março de 1886, Antero dá a lume o seu primeiro escrito filosófico desta sua fase terminal - "A filosofia da natureza dos naturalistas" $\left({ }^{15}\right)$ - suscitado pelo livro do brasileiro A. Viana de Lima, Exposé Sommaire des Théories Transformistes de Lamarck, Darwine Haeckel, Paris, 1886.

Envia esse estudo a Jaime Batalha Reis com uma carta em que considera: "Creio que pouco lhe agradará ali, e nem talvez sequer o estilo. Mas, sendo o meu primeiro escrito filosófico [Itálico nosso] não podia deixar de lho mandar. Se, lendo, lhe ocorrer alguma objeç̧ão grave comunique-ma (...) Este escrito foi coisa de ocasião e quase improvisado. Mas as ideias, é que não são improvisadas, antes representam o ponto a que cheguei no fim de anos de reflexão. (...) [Itálicos nossos] V. poderá avaliar por ali, sobretudo, as minhas tendências actuais" $\left({ }^{16}\right)$.

Volvidos cerca de oito meses, em 12 de Novembro, em carta a Fernando Leal, insiste em que "O Pessimismo não é um ponto de chegada, mas um caminho. É a síntese das negações na esfera da

$\left({ }^{14}\right)$ Idem, ibidem, pp. 761-762.

(15) V. Antero de Quental, Obras Completas III Filosofia, não só o texto mas também os comentários reunidos.

$\left({ }^{16}\right)$ Antero de Quental, Cartas II, ob. cit., pp. 771-772. 


\section{O último escrito filosofico de Antero de Quental}

natureza, a luz implacável caída sobre o acervo de ilusões das coisas naturais. Mas, para além da natureza, ou, se quiser, escondido, envolvido no mais íntimo dela, está o mundo moral, que é o verdadeiro mundo, ao qual a harmonia, a liberdade e o optimismo são tão inerentes, como ao outro a luta cega, a fatalidade e o pessimismo. Afinal, não vivemos verdadeiramente senão na proporção do que partilhamos desse mundo intimo e perfeito, ou, mais exactamente, da parte dele que desentranhamos de nós mesmos e fixamos nos nossos pensamentos, nos nossos sentimentos e nos nossos actos. [Itálicos nossos] Já vê que a existência tem um fim, uma razão de ser; e o Fernando, embora diga sinceramente o contrário, no fundo não o crê. Lá no fundo do seu coração há uma voz humilde, mas que nada faz calar, a protestar, a dizer-lhe que há alguma coisa porque se existe e porque vale a pena existir. Escute essa voz, provoque-a, familiarize-se com ela e verá como cada vez mais se lhe torna perceptível, cada vez fala mais alto, ao ponto de a não ouvir senão a ela e de o rumor do mundo, por ela abafado, não lhe chegar já senão como zumbido, um murmúrio, de que até se duvida se terá verdadeira realidade. Essa, meu amigo, é a verdadeira revelação, é o Evangelho eterno, porque é a expressão da essência pura e última do Homem, e até de todas as coisas, mas só no homem tornada consciência e dotada de voz. Ouça essa voz e não se entristeça".

E, em P. S., referindo-se aos "20 ou 30 dos [seus] últimos sonetos", informa: "Meti neles o melhor da minha Filosofia, à espera do dia em que a possa desenvolver largamente e em boa prosa. Mas, uma Filosofia nova, em versos obscuros e poucos, quem diabo pode entrar com ela?"[Itálico nosso] $\left({ }^{17}\right)$.

Dois dias depois, escrevendo a Jaime de Magalhães Lima, desenvolve aquilo que acabara de sugerir no que acabou de ler-se acerca da superação do "pessimismo".

"O que triunfa e o que fica [dessa superação] é aquilo que está para além do naturalismo, aquilo que no homem não é já filho da natureza, mas superior a ela e autónomo: a vida da consciência e a sua mais alta expressão, o sentimento moral. Aos poderosíssimos dissolventes e reagentes da crítica (essa química da razão) só isso pode resistir, porque é um facto, um facto evidente e, para o homem o mais positivo

(") Idem, ibidem, pp. 801-802. 
dos factos, porque o sente em si e o verifica a cada instante: e não se dissolveu, porque é um elemento simples, o núcleo da coisa complicadíssima chamada homem, o seu ser íntimo e verdadeiro. E, chegada a este ponto, a inteligência olha para trás, olha para a grande máquina da natureza, que o pessimismo lhe fez ver como uma coisa bruta e por si inexpressiva e sinistra, e pergunta a si mesma se aquele princípio que ela descobriu no homem, aquele núcleo não natural, desse ser aliás natural, não será também o princípio oculto da confusa natureza, e se o universo não gravitará, obscuramente, inconscientemente, para onde gravita o homem com um pouco de luz e um pouco de consciência? Se nãoé assim, ouniversoé uma monstruosidade e a consciência humana a mais inexplicável de todas as ilusões: o que equivale a dizer, o Ser, sob todas as suas formas, é um absurdo. Mas pode isto ser assim? não chamaria o senso comum e o sentir geral da humanidade louco simplesmente a quem tal pretendesse? Toda a actividade dos homens, há muitos milhares de anos, a sua actividade superior, que é só a que afinal se vê e fica, nuanifestada em todas as suas obras e instituições, afirma implicitamente a autonomia da vida moral $e$ a identidade fundamental dela com o princípio oculto da actividade do universo: afirma-a, porque a pressupõe; pois, se a não pressupusesse, se não partisse dessa como que evidência inconsciente, para que trabalhar? para que sacrificar-se? para que viver? O facto, pois, o simples facto da história prova (com uma força probante sui generis mas invencivel para quem se reconhece homem) a identidade da vida moral e do princípio do universo. [Itálicos nossos]

E ainda na mesma carta discorria deste jeito: "(...) preocupado como ando há anos com a evolução ulterior do pensamento moderno, que eu entendo caminhar para uma compreensão sintética das coisas, ao mesmo tempo idealista e naturalista, isto é, idealista dentro do naturalismo, e optimista dentro do pessimismo, e tendo eu mesmo trabalhado muito para achar as fórmulas, ainda hoje indecisas, dessa grande síntese, fui insensivelmente levado a dar-lhe uma ideia da orientação dos meus pensamentos, e mostrar-lhe como é que concebo que sem se sair do naturalismo (quero dizer sair para o sobrenaturalismo) se pode, pela aprofundação da natureza humana (e, por analogia invencível, de toda a natureza) chegar ao mais completo espiritualismo, a um pampsiquismo que se acomoda perfeitamente, ou antes, harmoniza necessariamente, com o determinismoe ainda materialismo 
das ciências naturais e a concepção do mundo natural que delas sai, sem sacrificar nenhum daqueles princípios que fizeram sempre do espiritualismo, ainda nas suas formas mais imperfeitas, a filosofia por excelência popular entre os homens" $\left({ }^{18}\right)$.

$\mathrm{Na}$ véspera de Natal desse mesmo ano, em carta a Maria Amália Vaz de Carvalho, ao agradecer os artigos da escritora sobre os Sonetos Completos, considera: "o meu livrinho, apenas aqui ou ali em meia dúzia dos últimos sonetos, fere a nota exacta e sã, porque infelizmente morreu-me o dom dos versos, precisamente quando começava a pensar e a sentir alguma coisa que realmente merecesse ser posta em verso". [Itálicos nossos]

$\mathrm{E}$, após algumas considerações muito discretas acerca das relações da sua poesia com o Budismo que Oliveira Martins no prefácio ao livro achara por bem exarar, escreve: "O processo gigantesco do naturalismo, filho de uma civilização poderosa e complexa como nenhuma, só poderá ser equilibrado por um progresso equivalente ao do ascetismo. [Itálicos nossos] Sem esse equilíbrio a sociedade moderna, que já hoje nos causa mais terror do que admiração, poderá continuar ainda por algum tempo de poderosa, tornada formidável, e, de formidável, bestial; mas o homem, o verdadeiro homem, isto é, o homem moral, terá morrido: e, morto ele, tudo cairá, porque só ele sustenta a grande mole social. A sociedade é, antes de tudo, um facto de ordem moral". E logo acrescenta: "Mas não continuo com estas reflexões, porque desejo fazer delas o assunto de um escrito, até certo ponto [Itálico nosso] em resposta aos artigos de V. Ex. ${ }^{\text {a" }}\left({ }^{19}\right)$.

De Março a parte de Outubro de 1887, Antero trocara a tranquilidade de Vila do Conde pelas inquietações familiares de Ponta Delgada, donde escreve, em 14 de Maio, a Wilhelm Storck, a bem conhecida carta bio-bibliográfica que o tradutor alemão dos Sonetos lhe havia pedido.

Depois de referir a importância da obra de Hegel na sua especulação, assim como de Hartmann, Lange, Du Bois-Raimond, Leibniz, Kant e outros, confidencia: "Não sei se poderei realizar, como tenho desejo,

$\left({ }^{18}\right)$ Idem, ibidem, pp. 803-805.

$\left({ }^{19}\right)$ Idem, ibidem, pp. 808-809. O "escrito" projectado não foi publicado. É nossa convicção que esse falhado projecto teria em vista rebater as considerações de Oliveira Martins acerca do budismo anteriano, exaradas no prefácio a Sonetos Completos. É que o melindre da situação era evidente... 
a exposição dogmática das minhas ideias filosóficas. Quisera concentrar nessa obra suprema toda a actividade dos anos que me restam a viver. Desconfio, porém, que não o conseguirei: a doença que me ataca os centros nervosos, não me permite esforço tão grande e tão aturado como fora indispensável para levar a cabo tão grande empresa. Morrerei, porém, com a satisfação de ter entrevisto a direç̧ão definitiva do pensamento europeu, o Norte para onde se inclina a divina bússola do espírito humano. [Itálicos nossos] Morrerei também, depois de uma vida moralmente tão agitada e dolorosa, na placidez de pensamentos tão irmãos das mais íntimas aspirações da alma humana, e, como diziam os antigos, na paz do Senhor! - Assim o espero" $\left({ }^{20}\right)$.

Ainda de Ponta Delgada, pelos fins de Maio, escreve a Oliveira Martins; "Vejo-o caminhar para um pessimismo negativo, que não posso aprovar e me contrista. Refere-se V. ao tempo em que a vida "era para nós menos livre, no sentido budista, isto é, muito menos vazia". O progresso espiritual apresenta-se-lhe pois como negativo, e a última palavra da existência como uma vacuidade sem solução e como que forçada. Se reflectir bem verá que não pode ser assim, sob pena de não serem o universo e a existência mais do que um absurdo. [Itálicos nossos] Se o fenómeno é vão, é justamente porque para além dele está alguma coisa que não é vã. E se a liberdade se afirma pelo desprendimento das coisas vãs, é justamente porque a liberdade é em si mesma realidade superior, e a verdadeira realidade, não negativa, por conseguinte, mas essencialmente afirmativa. [Itálicos nossos] De quê? De si mesma, isto é, da essência última do Ser, dificílima de definir, é verdade, pelas nossas fórmulas metafísicas, mas clara e perceptível ao sentimento moral, que é a sua manifestação adequada, a sua realização. Se a liberdade é o bem, não pode ser abraçada como um pis aller, com relutância, com desgosto e saudade da não-liberdade: isso implicaria contradição. E a tendência última das coisas, contrariada tão terrivelmente no curso da Natureza pela imperfeição do inconsciente (aliás sapientíssimo), [Itálicos nossos] não pode, ao realizar-se na consciência, produzir o efeito duma desilusão e duma queda no vácuo. Logo, não acuse o Ser, nem calunie o Budismo. O Ser fez-nos para a beatitude; eo Budismo trazconsigo toda a satisfação, toda a consolação e toda a alegria. [Itálicos nossos] Não é tão consolador conhecermos

$\left({ }^{20}\right)$ Idem, ibidem, pp. 833-840. Especialmente, p. 839. 
que somos loucos? que as coisas que nos atormentam são puras virtualidades? que os nossos grandes males, os nossos grandes infernos, bem no fundo, não existem, e que esses terríveis espectros são meras ilusões de óptica? A contemplação da nossa toleima é muito salutar $e$, tudo bem pensado, fonte perene de alegria. A verdadeira ironia transcendental é esta [Itálicos nossos], a única verdadeiramente filosofica, humana, superior. A outra (que me parece ser a do Renan), julgo-a apenas um último requinte da vaidade, a saber, a vaidade de ser superior a todas as vaidades. É a presunção da inteligência [Itálicos nossos], nada mais. Pois começa, celta dengue e pretensioso, por te rir de ti mesmo, rir-te dessa última e suprema vaidade, e então direi que começas a ter alguma transcendência. Quanto a mim, meu querido amigo, cada vez me convenço mais de que - na impossibilidade de penetrarmos absolutamente, totalmente até ao fundo do problema da existência - ainda assim a humildade do coração nos aproxima mais da Verdade do que o orgulho da inteligência. Ora, desprezar o mundo, desprezar os homens, ver o vácuo e o tédio como resíduo final de tudo, é grande pecado de orgulho. Afinal, o que está está bem, o que vai vai bem. A nós o que nos cumpre é descobrir o como e o porquê deste paradoxo universal das coisas - na certeza de que é um divino paradoxo." [Itálicos nossos] $\left({ }^{21}\right)$.

Retornado a Vila do Conde, em Fevereiro de 1888, mostra-se receptivo acerca da hipótese de um cargo de professor no Curso Superior de Letras, mas com a condição de não ser a Filosofia, mas o Latim, o objecto do seu possível ensino. E isso porque "é claro que quem tem, como eu, ideias tão pessoais sobre o assunto, e tão diversas das recebidas, não se pode sujeitar a ensinar a Filosofia oficial" ${ }^{(22}$ ).

Com efeito, há suficientes indícios de que Antero se preparou para a falaz hipótese de concretização de tal magistério $\left({ }^{23}\right)$.

Em Setembro desse mesmo ano, em carta a Manuel Ferreira Deusdado, discreteia por este modo: "Apesar da minha grande tendência para o dogmatismo (tendência incorrigível, mas bem desculpável em quem foi sempre mais poeta do que filósofo [Itálicos nossos]) aprovo

( ${ }^{21}$ ) Idem, ibidem, pp. 841-842.

(22) Idem, ibidem, p. 865.

$\left({ }^{23}\right)$ V. Idem, ibidem, pp. 873 e 891 . V. outrossim o testemunho de Henrique das Neves in José Bruno Carreiro, Antero de Quental, vol. II, Ponta Delgada, 1948, pp. 183-184. 
aquela prudente reserva [do livro de Deusdado] e reconheço que, provisoriamente, é muito mais proveitoso analisar do que construir: é desbravar o terreno para futuras sínteses, acumular os elementos para a construção definitiva, que seria temerário tentar desde já. [Itálicos nossos] A "volta a Kant", como dizem os alemães, estava indicada desde que uma multidão de factos novos, nas ciências naturais, na psicologia e na história veio patentear as lacunas e a insuficiência das antigas sínteses; $e$ a aliança do kantismo com $o$ espiritualismo, ou antes a profunda renovação deste por aquele, parece-me o facto mais considerável do pensamento filosófico nos últimos vinte anos. [Itálicos nossos] A filosofia não pode prescindir dos dados da consciência; mas, por outro lado, as aspirações da consciência não podem anular os factos naturais e históricos provados e positivos. A resolução desta antinomia, a explicação do Universo pela consciência, mas, ao mesmo tempo, a interpretação da consciência por princípios análogos às leis fundamentais do Universo, a unidade do ser e do Universo, a unidade do ser e do saber que Hegel tentou demonstrar só dialecticamente e, por isso, insuficientemente, [Itálicos nossos] parece-me mais acessível pelo caminho do Neokantismo, do que por outro qualquer. Não posso pois senão felicitar a V. Ex. ${ }^{a}$ pelas tendências e direç̧ão intelectual que o seu livro revela. Embora a psicologia, propriamente dita, solicite mais a sua atenção do que as questões metafísicas, entretanto exprime-se V. Ex. ${ }^{2}$ de modo a deixar ver que não considera caducos e abolidos aqueles problemas só pelo facto de não poderem ser resolvidos senão indirectamente e sempre com um grande elemento de hipótese. Tudo isto está de acordo com as tendências mais legítimas do pensamento moderno e é deste modo que a luz se irá fazendo gradualmente, até se reconhecer que $o$ espírito humano não é fragmento truncado e incompreensivel ou uma coisa à parte e isoladano meio do Universo, mas sim um elementofundamental dele e a mais alta potência e expressão da sua essência. [Itálicos nossos] A metafísica e o espiritualismo só poderão ser destruídos quando ao mesmo tempo forem abolidas a razãoe a consciência humanas" $\left({ }^{24}\right)$.

Pelos fins desse mesmo ano, a propósito do livro de Max Nordau,

(24) Antero de Quental, Cartas II, ob. cit., pp. 900-901. 
Les Mensonges Conventionnelles de. Notre Civilization, transmite a Oliveira Martins o seu juízo e as considerações que essa obra lhe suscitara: "Não me agradou o livro do Nordau. Tantas ilusões, tanto optimismo e tão pouco espírito crítico, em sujeito que se apresenta como o representante da razão científica, em face das mentiras da sociedade actual, chegaram a irritar-me. De resto, parece-me homem muito moço, e nesse caso tem alguma desculpa. Mas sempre queria dizer ao Sr. Nordau, para seu ensino, que não está tudo em se saber cientificamente que uma coisa é errónea, para se condenar, e sobretudo para se afirmar que pode ser substituída. Para isso era necessário que a mola real do homem e da sociedade fosse a razão teórica, e a sua razão principal a verdade. Mas a verdade humana e social não é a verdade científica. Os científicos não são capazes de compreender isto, exactamente como os ideólogos do século passado (com quem se parecem muito, e julgo que para pior) e como o próprio de tais espíritos estreitos e científicos é a presunção e o optimismo atrevido, a sua influência será ainda mais nociva do que a dos ideólogos, que ao menos partiam de princípios psicológicos. Decididamente, a inteligência humana é fraca e acanhada de mais para poder compreender, dominar e governar coisa tão complexa como é o mesmo homem. $O$ instinto, afinal, valia muito mais para esse fim. Infelizmente $o$ periodo do instinto passou, e é nisso justamente que está a crise: substituir, na direcção das coisas humanas, o instinto que era suficiente, pela inteligência, que parece insuficientíssima. Não vejo saída a este beco escuro." [Itálicos nossos, a partir de "Decididamente"] $\left(^{25}\right)$.

Ao entrar o ano de 1889, durante o qual, como já foi lembrado, seria escrito "Tendências gerais da filosofia na segunda metade do século XIX", de passagem, desabafa: "(...) eu é que já absolutamente não sei fazer versos, nem tenho que dizer em verso" $\left.{ }^{26}\right)$.

E logo pouco depois, em carta a Maria Amália Vaz de Carvalho, desabafa: "O homem, minha nobre Amiga, esse famoso 'animal racional', aquilo que de justamente tem menos é de racional, e enquanto se lhe falar só à inteligência consegue-se pouco dele. Veremos se uma filosofia mais profunda, que está incubando e apenas por ora

$\left({ }^{25}\right)$ Idem, ibidem, pp. 909-910.

$\left({ }^{26}\right)$ Idem, ibidem, p. 921. 
se denuncia por certos sintomas esporádicos, é capaz de descobriro caminho secreto das suas simpatias e da sua confiança." [Itálicos nossos] E logo afirma: "O Transcendentalismo tem de ser restaurado, de um feitio ou de outro. Só ele pode satisfazer, ou, pelo menos, iludir e entreter as desmedidas aspiraç̃̃es, as ambições e esperanças incorrigíveis do coração humano. Sem isso receio que, apesar de toda a ciência que já há, e da muita que se há-de ainda ir produzindo e acumulando (coisa aliás excelente e até indispensável), o bipede singular que inventou Deus e pôs a virtude, que se não vê nem palpa, acima de todos os bens visíveis e palpáveis deste mundo, o bipede capaz destes sublimes paradoxos não tenha outra alternativa, para não cair numa soez mediocridade, senão a de uma maldade diabólica" [Itálicos nossos] $\left.{ }^{27}\right)$.

Ora, eis que neste percurso cronológico em busca dos sinais que Antero, esparsamente, nos foi legando, se reencontra o testemunho pelo qual se principiou: "os meus estudos e pensamentos filosófi$\cos ^{\prime \prime}\left({ }^{28}\right)$ os quais, volvidos alguns bons meses, se concretizariam na redacção do seu último escrito filosófico, objecto destas páginas.

Todavia, segundo se ajuíza, não deixará de ter interesse considerar ainda um testemunho de Agosto de 1889 que haverá de algum modo, coincidido com os trabalhos de pensamentoe de redacção do testamento filosófico anteriano. É uma carta ao poeta António Molarinho (1860-1890) datada da Praia da Granja, 26 de Agosto de 1889.

"A poesia tem embalado, com a sua divina melopeia, as dores da humanidade, tem atormentadoo sentimento acerbo das suas inenarráveis misérias: mas essas dores, essas misérias não as pode ela suprimir. A ciência e a democracia suprimi-las-ão talvez. Como, não sei. Ninguém sabe. Mas é essa a fé deste século audaz, e a fé tem sido sempre o pressentimento de alguma grande renovação histórica, de alguma nova revelação da humanidade. Quero ter eu também essa fé e quase direi como Tertuliano: credo quia absurdum.

Com tudo isso, meu caro poeta, o momento presente é triste, é amargo. Sentimo-nos tão deslocados! Parece-nos este mundo tão pouco o nosso mundo! Quase que temos a consciência duma gradual fossilização, da transformação lenta da nossa carne e do nosso sangue

\footnotetext{
$\left({ }^{27}\right)$ Idem, ibidem, 928-929.

${ }^{(28)}$ V. p. 1 deste estudo.
} 


\section{O último escrito filosófico de Antero de Quental}

numa substância estranha, morta, mineral, sentimos que alguma coisa nos soterra e a pouco e pouco nos reduz ao estado de seres paleontológicos, representantes dum período já obsoleto nas sucessivas estratificações históricas da humanidade.

É que somos, com efeito, os representantes duma espécie prestes a desaparecer - e é força que se cumpram os decretos do destino... $\left({ }^{29}\right)$.

Desapareçamos pois de bom grado. Não se aflija. No fundo do verdadeiro poeta há sempre um crente. Apele para as energias superiores da sua alma, pense que a arte, por bela e sedutora que seja, não é ainda assim mais do que um reflexo, um símbolo do ideal supremo da vida moral, e que esse ideal, subsistente em si e por si, não precisa de formas, caducas afinal ainda as mais esplêndidas, para se afirmar, pois o que é tira-o de si, da sua substância inesgotável, espiritual, infinita. Depois a vida, a nossa vida individual e humana, é tão pouca coisa! Se se não pode passar cantando, passa-se de outro modo. $\mathrm{E}$ as vezes vale mais isso. Creia que a virtude pode mais e é mais que a arte [Itálicos nossos] E dura mais também: dura eternamente. As obras do bem, ligadas indissoluvelmente à substância do universo, absorvidas, desde o momento da sua produção, para nunca mais saírem dele, vinculadas, pela cadeia duma causalidade superior, a todas as suas evoluções através dos tempos, dos espaços, dos mundos, vão aumentar o tesouro da energia espiritual das coisas, fecundá-las nos seus mais íntimos recessos e, sempre presentes, sempre activas, eternizam, nessa sua perene influência, a alma donde uma vez saíram. O universo só dura pelo bem que nele se produz. Esse bem é às vezes poesia $\mathrm{e}$ arte. Outras vezes é outra coisa. Mas no fundo é sempre o bem e tanto basta" $\left({ }^{30}\right)$.

Ao escrever tão belas coisas - tão belas e tão autênticas -, Antero abre pistas para a compreensão da sua rota em busca de um porto de salvação. Ensaiar-se-á, oportunamente, o entendimento das dificuldades encontradas e das soluções que foi entrevendo.

$\left({ }^{29}\right)$ Comparar com o escrito de Antero, "O futuro da música", 1866, no qual se profetiza a morte da arte dos sons, V. Antero de Quental, Obras Completas, Filosofia, Lisboa, 1991.

$\left({ }^{30}\right)$ Antero de Quental, Cartas II, ob. cit., p. 953. 


\author{
Antero ensinou a pensar \\ em ritmo; descobriu-nos \\ a verdade de que o ser \\ imbecil não é indispensável \\ a um poeta.
}

Fernando Pessoa

É bem sabido que Platão (429-347 a. C.), em A República mais ou menos utópica que delineou, excluía da polis a poesia, reconhecendo, além do mais, "que é antigo o diferendo entre a filosofia e a poesia" $\left.{ }^{31}\right)$. Mas também não é menos conhecido que, como bom discípulo, Aristóteles (384-322 a. C.) na sua Poética não navegaria pelas mesmas águas.

Assim, desde as origens da nossa europeia tradição filosófica, a poesia foi ou não objecto de algum escândalo em si mesma ou sobretudo nas conexões implícitas ou explícitas com a tarefa especulativa. Mas isso não impediu que ela tenha coexistido ou se entrosado de modo mais patente ou mais oculto com a especulação formal ideativa.

No tocante a Portugal, e tendo em vista tão-só tempos recentes, logo se podem lembrar os casos de Teixeira de Pascoaes (1877-1952), de António Sérgio (1883-1969), de Leonardo Coimbra (1883-1936), de Vieira de Almeida (1888-1961) e de Fernando Pessoa (1888-1935).

Com efeito, ainda que por modos e formas divergentes, tais personalidades culminantes da nossa cultura experienciaram e equacionaram, tal lhes foi sendo necessário, o problema da convergência ou conflito ou paralelismo entre as linguagens filosofica e poética que lhes foi dado utilizarem.

No tocante a Teixeira de Pascoaes $\left({ }^{32}\right)$ e a Fernando Pessoa $\left({ }^{33}\right)$, bem

${ }^{31}$ ) Platão, A República. Introdução, tradução e notas de Maria Helena da Rocha Pereira, 6." edição, Lisboa, 1990, p. 475.

$\left.{ }^{(32}\right)$ V. a excelente síntese de Jacinto do Prado Coelho, querido e malogrado amigo que recordo com saudade e lágrimas retidas, in Dicionário de Literatura, por ele dirigido, 3." edição, Porto, 1978, 3. volume, pp. 795-798.

$\left({ }^{33}\right)$ V. Fernando Pessoa, Textos Filosóficos, 2 volumes, Lisboa, 1968, estabelecidos e prefaciados por António Pina Coelho; e Obras de Fernando Pessoa. Organização, 
mais poetas que filosofos, como negar, todavia, a evidência da interconexão entre os seus poemas e os seus filosofemas?

Quanto a Leonardo Coimbra $\left({ }^{34}\right)$, tanto em A Alegria, a Dor e a Graça (1916), como em DoAmor eda Morte (1922), a vivência poética manifesta-se, porventura, de modo bem mais vivo do que as implícitas vivências filosóficas.

Ora, não deixa de ser motivo de alguma ponderação que tanto António Sérgio $\left({ }^{35}\right)$ como Vieira de Almeida $\left({ }^{36}\right)$, pensadores de índole e metodologias crítico-racionalistas, tenham buscado, por vezes, a expressão poética.

Com efeito, nos primórdios da sua actividade, Sérgio publicou Rimas, 1908, sobre as quais viria a pronunciar-se negativamente, considerando que a sua vocação não era essa.

Quanto a Vieira de Almeida, o caso é diverso: aos trinta e três anos deu a lume Bucólicas - Lacrimae Rerum I e, treze anos após, Lacrimae Rerum - Nocturna II. Não se trata, pois, neste pensador de alto quilate, de qualquer "pecadilho" da mocidade mas da efectiva necessidade de expressão de vivências estéticas, aliás, nele extremamente despertas.

Pois bem! Verificado que em Portugal os filosofos se não têm mostrado muito dispostos a respeitar as injunções platónicas, reverta-se a Antero em cuja obra a interacção da poesia e da filosofia constituiu um dos aspectos fundamentais do devir da sua mundividência.

Com efeito, fundamentalmente, no seu percurso poético-filosófico podem demarcar-se grosso modo os seguintes períodos: 1) 1861-1865; 2) $1871-1875$; 3) 1876-1880; 4) 1881-1890.

introdução e notas de António Quadros, Porto, 1986, III vol., "Páginas de reflexão filosófica", pp. 205-536; e ainda Fernando Pessoa Cidadão do Imaginário, Lisboa, 1985 , de nossa autoria.

${ }^{(34}$ V. José Marinho, O Pensamento Filosófico de Leonardo de Coimbra, Porto, 1945 e Verdade, Condição e Destino no Pensamento Português Contemporâneo, Porto, 1976, cap. V "Leonardo Coimbra e o magistério do amor e da liberdade", pp. 93-122.

$\left.{ }^{35}\right)$ V. "Para uma apologia de António Sérgio I A dialéctica dos fins e dos meios II O meio por excelência - a educação" in Portugueses Somos, da nossa autoria, Lisboa, 1975, pp. 75-119.

$\left.{ }^{(36}\right)$ V. Rogério Fernandes, "A Filosofia de Vieira de Almeida no seu contexto ideológico" e, de nossa autoria, "Vieira de Almeida ou uma filosofia do rigor" in Vieira de Almeida, Obra Filosófica I (1911-1940), Lisboa, 1986; Carlos Henrique do Carmo Silva, "A equação do ser e a inequação do pensar", Análise, n. ${ }^{\circ} 13$, Lisboa, 1989. 


\section{Antero de Quental}

O primeiro período é, além do tempo do descobrimento das virtualidades do soneto, a fase de Odes Modernas (1863-65) e do primeiro núcleo de escritos de índole filosófica; o segundo é o do Programa para os Trabalhos da Geração Nova e sua destruição; o terceiro é o que se baliza pela fracassada Teoria da Religião e pela poesia "Os Cativos" e outras do mesmo ciclo; e o quarto é o da fixação em Vila do Conde, onde conclui (como quem deseja terminar uma tarefa antiga e, de algum modo, "ultrapassada") os Sonetos e se propõe dedicar-se tão-só à aventura da reflexão filosófica.

Muito por alto e buscando, na perspectiva desta introdução, o que se nos afigura essencial, consideremos tais períodos um a um.

O período de 1861-65 dir-se-ia genesíaco do ponto de vista quer da poesia quer da filosofia que, sincreticamente, confluem para a mundividência que, por então, lhe era possível conceber.

Concluído em 1863, Odes Modernas seria dado a lume em 1865, a par das suas intuições e congeminações filosóficas de então. Às Odes, como é sabido, segue-se, a chamada "Questão Coimbrã".

Quanto à filosofia, ou melhor, aos primeiros delineamentos da sua procura de aspiração especulativa, dá a lume, sucessivamente: "A Bíblia da Humanidade de Michelet - Ensaio Crítico", "O sentimento da imortalidade", "Arte e Verdade - I Carácter positivo da arte", "Espontaneidade", e "O futuro da música" $\left({ }^{37}\right)$.

Escritos filosóficos ou para-filosóficos de aprendiz de talento, eles denunciam, todavia, como que a rosa-dos-ventos das suas inquietações desse tempo, algumas das quais apontam, se bem nos parece, para a origem daquilo que seria a longa, sinuosa e dramática procura da sua vida - a filosofia capaz de explicitar o sentido, por então ainda bem nebuloso, das motivações racionais para actuar na transformação da sociedade e de si próprio.

O segundo período, após Causas da Decadência dos Povos Peninsulares nos Últimos Três Séculos (1871), caracteriza-se pela busca quer de soluções políticas inovadoras para a sociedade portuguesa como, em 1873, o projecto da União Democrática Portuguesa $\left({ }^{38}\right)$ quer,

$\left({ }^{37}\right)$ V. estes textos e respectivos comentários em Antero de Quental, Obras Completas III, Filosofia, Lisboa, 1991.

${ }^{38}$ ) V. Manuel Simões, "Antero Inédito - O programa da União Democrática", Brotéria, Maio-Junho de 1987, pp. 483-493. 
de 1871 a 1875?, a fracassada elaboração do Programa para os Trabalhos da Geração Nova $\left({ }^{39}\right)$, o qual viria a soçobrar ante dificuldades filosóficas que não lograra equacionar em termos que lhe dessem tranquilidade íntima. Ou seja: o Programa morrera porque Antero não fora capaz de encontrar para ele a filosofia idónea e consentânea com as exigências que considerara necessárias.

No terceiro período (1876-1880), conhecem-se indícios, infelizmente parcos, acerca de uma Teoria da Religião na qual, porventura, teria procurado reequacionar problemas filosóficos não resolvidos e "adiados" na conjuntura do Programa.

Desencadeada uma dada sorte de crise "existencial", a expressão das inquietações poético-fïlosóficas de então vem à superfície, sobretudo, nas chamadas "poesias lúgubres" $\left({ }^{40}\right)$, uma espécie de dramática confissão do malogro ante a sua busca da viabilidade do Bem tal o entressonhava por entre o negrume do Mal entrevisto e experimentado na caminhada dos homens no devir temporal.

No quarto período (1881-90), Antero "refugiado", tanto quanto lhe ia sendo possível, em Vila do Conde, publica Sonetos Completos terminados em 1885 e dado a lume no ano seguinte; e considerando definitivamente concluída (por razões fundas de metodologia?) a sua caminhada poética, aliás, coroada pelos mais eloquentes aplausos da intelectualidade lusa e até estrangeira, dedicar-se-ia, a partir dessa data crucial e em termos exclusivos, à reflexão filosófica cujo afloramento público seria a revelação, em 1890, de "Tendências gerais da filosofia na segunda metade do século XIX".

Ora, nodecurso desta sua acidentada "viagem" cujos sinais exteriores se procuraram entrever, e como que fazendo parte de um "outro" Antero oculto, a escrita de sonetos manteve-se permanente de 1860-61 a 1885, ou seja, dos dezoito aos quarenta e três anos $\left({ }^{41}\right)$. E em nenhum desses anos o poeta deixou de escrever, pelo menos, um soneto.

$\left.{ }^{(39}\right)$ V. da nossa autoria, Antero e a Ruína do seu "Programa", (1871-1875), Lisboa, 1988.

$\left.{ }^{(40}\right)$ "Hino da Manhã" e Outras Poesias do Mesmo Ciclo, edição, estudo introdutório e notas da nossa autoria, Lisboa, 1989.

$\left.{ }^{41}\right)$ V. Ruy Galvão de Carvalho, "Ordenação cronológica dos Sonetos Completos de Antero de Quental" in Antero de Quental-Novos Ensaios, Vila Franca do Campo, S. Miguel, 1985, pp. 153-173, e "Hino da Manhã" e Outras Poesias do Mesmo Ciclo, da nossa autoria, Lisboa, 1989, pp. 29-32. 
No decurso dessa "viagem" entrevêem-se três ciclos no tocante à fecundidade sonetística: 1863-69, 1871-76, 1877-85.

O primeiro, se acertarmos no alvo, teria sido o período do descobrimento das virtualidades do soneto no tocante à convergência da estesia poética e do filosofema ainda que necessariamente sincrético; o segundo corresponderia à primeira grande crise existencial desencadeada pelo fracasso da busca filosofante; $e$ o terceiro à paulatina ainda que acidentada "viagem" na busca da convergência entre as virtualidades do poema e a complexidade crescente do filosofema.

E é então que ocorre a enigmática morte do "dom dos versos" $\left({ }^{42}\right)$ pois que eles teriam deixado de poder ser mediação suficiente e adequada para a expressão dos filosofemas cada vez mais complexos a que Antero fora e ia logrando aceder.

E em síntese de sínteses ou, acaso, trilhando uma dada sorte de via indutiva, afigura-se-nos legítimo aventar as seguintes hipóteses que, com humildade, se propõem, a quem esteja disponível para verificar, corroborar ou invalidar a sua eventual pertinência.

A primeira de tais hipóteses respeita à conexão entre soneto e filosofema no contexto da "viagem" anteriana.

Com efeito, Antero teria entrevisto, no evolver da sua experiência de poeta para-filosófico, a possibilidade de "cristalizar" em soneto dada ou dadas vivências de teor reflexivo. E daí que o tenha tentado, por exemplo, em relação à "ideia" hegeliana. Somente, em vez de um soneto logo se lhe desdobraram oito. E porquê? Bem... A hipótese que se aventa é que logo se lhe tornara inviável delinear tal filosofema nos catorze versos bem medidos impostos pela estrita formalidade do soneto. E, com efeito, se "A ideia" obrigara o poeta a um desenvolvimento em oito sonetos, o mesmo viria a acontecer, depois, com outros temas: "Elogio da morte" exigiria seis sonetos; e "Tese e antítese", "Disputa em família", "Espiritualismo", "Evolução", "Redenção" cada um desses temas impôs, formalmente, ao poeta dois sonetos.

Ora, por mais exímio sonetista que Antero fosse - e era-o -, a sua longa experiência nessa modalidade de expressão poemática ter-lhe-ia ido demonstrando que dados filosofemas ou experiências existenciais

$\left({ }^{42}\right)$ Pede-se ao leitor atento que, à luz dessa hipótese, releia as confidências exaradas em II deste breve estudo. 


\section{O último escrito filosófico de Antero de Quental}

de cariz filosófico aos quais ia acedendo excediam, de todo, as virtualidades expressivas dessa composição poética. Com efeito, pelo que nos toca, ignora-se de todo a existência de qualquer obra significativa de filosofia moldada em sonetos...

E daí que decorra a hipótese de que a experiência levada a efeito, no período de 1874-81, das chamadas "poesias lúgubres" terá tido alguma relação com o anterior percurso poético-filosófico anteriano. Não obedecendo à formalidade do soneto-interrogamo-nos-e espraiando-se com uma liberdade bem outra mediante tantas quadras quantas as consideradas necessárias, seria essa via a fórmula tentada por Antero para prolongar a sua experiência de conjugar poema e filosofema? Seria? E, por seu turno, o seu fracasso, ao olhar e à intenções anterianas, estaria na origem da destruição dessas poesias? $\left({ }^{43}\right)$.

A respeito dos problemas formulados, importa lembrar ou relembrar que no período em que essas poesias foram compostas e destruídas, os malogros filosóficos do seu autor, afinal, tinham-no enriquecido e a sua "viagem" em busca de filosofemas cada vez mais complexos e, portanto, mais "distantes" da possibilidade de os exprimir poeticamente, o obrigara a limitar e a ir terminando a sua passada e brilhante "carreira" de sonetista. Com efeito, a partir de 82, a escrita de sonetos declina até findar, e para sempre, em 1885.

É que, entretanto, no complexo percurso anteriano, o filosofema assume ou tende a assumir preeminência relativamente ao poema que tendia à secundarização no processus mental em apreço.

$\mathrm{Na}$ verdade, quem o saberia ou poderia ter sabido melhor do que o nosso poeta-filosofo que, enfim, ele era ou ia sendo um filosofo em vias de encontrar a autonomia e a originalidade - ou seja, a sua voz - no percurso que intentava levar a efeito?

Para além dos testemunhos epistolares já registados, "A filosofia da natureza dos naturalistas" (1886) e "Tendências gerais da filosofia na segunda metade do século XIX" (1890) bem mostrariam que assim fora e assim ia sendo.

Ora, - interrogamo-nos - algo do que aí ficou mais sugerido do que demonstrado tende a insinuar que a assunção anteriana da linguagem

$\left({ }^{43}\right)$ "Os cativos", 13 quadras; "Os vencidos", 20 quadras; "Entre sombras", 9 quadras; "Hino da Manhã", 32 quadras; "A fada negra", 11 quadras.

Verificar em "Hino da Manhã" e Outras Poesias do Mesmo Ciclo, edição, estudo introdutório e notas da nossa autoria, Lisboa, 1989, pp. 39-59. 
e da postura filosóficas implicara a "morte" do poeta tal como o autor de Sonetos Completos sugere ou insinua, repetidamente, nas confidências epistolares que se averbaram no cap. II deste estudo?

Em boa verdade, não foi nem é essa a nossa intenção e se, acaso, ela aflorou à superfície da complexa trama em causa, isso seria como que uma excessiva ou ingénua simplificação da real complexidade da fenomenologia em apreço.

Como é evidente, Antero jamais esqueceu ou poderia ter esquecido que, no sinuoso e complexo devir de vinte e cinco anos, escrevera poesia e sobretudo os Sonetos que se foram, em 1885, adjectivados de Completos, isso teria ocorrido devido a uma decisão pessoal e programática pois que, na sua perspectiva, a filosofia a explicitar necessariamente o exigia, e a hora disso acontecer chegara ou ia chegando, enfim. Ou seja: após os fracassos sucessivos do Programa para os Trabalhos da Geração Nova, da Teoria da Religião e ainda do Ensaio sobre as Bases Filosóficas da Moral ou Filosofia da Liberdade $\left({ }^{44}\right)$, os quais, ai dele!, ninguém os conhecera e conhecia melhor do que o "frustrado" filosófo, a partir de 1885, este encontrara ou julgava ter encontrado, enfim, o seu rumo viável e salvador.

Ora, terá sido por este modo que, efectivamente, os sucessos ocorreram?

Em face dos dados documentais reunidos no capítulo anterior, com efeito, assim se nos afigura que as coisas - complexas coisas, aliás tenham ocorrido. Mas como, e felizmente, "há mais coisas no Céu e na Terra do que julga a tua filosofia", sugere-se a quem nos tenha seguido até aqui o favor de voltar a considerar os testemunhos do próprio Antero reunidos anteriormente. $E$ se tal leitor atento ajuizar que a verdade dos sucessos é outra, o que é muito provável, resta-nos esperar, e com alguma e natural ansiedade, que ele nos corrija e colabore na procura em causa.

Ah! Esquecíamo-nos de exarar aqui algo que, aliás, se nos apresenta como evidente. Éo seguinte: não foi, não poderia ter sido impunemente que Antero, durante mais de vinte anos, tenha usado como meio privilegiado de expressão a linguagem poética de acordo com os seus cânones próprios. Ora, isso teve um "preço" pois não há diques

${ }^{\left({ }^{44}\right)}$ V. comentários nossos a esse texto in Antero de Quental, Obras Completas III Filosofia, Lisboa, 1991. 


\section{O último escrito filosófico de Antero de Quental}

intransponíveis na mente humana. É que, em boa e chã verdade, a derradeira tentativa filosófica que se considera está impregnada, sobretudo no terceiro e derradeiro capítulo, de um alor ou de um ímpeto ou de um "olhar" que tem não pouco a ver com a experiência poética do seu autor. Ou, ainda, por outras palavras: tal filosofia, independentemente da qualidade a que tenha logrado alçar-se, mergulha algumas das suas raízes em vivências de índole claramente poética. $\mathrm{E}$ mais, e porventura indo mais fundo: essa filosofia remete-nos outrossim para algo que a transcende mas em que ela se embebe.

É esse "algo" que se buscará entrever, apenas entrever, no seguinte e último capítulo desta tão fruste introdução.

\section{IV}

\section{Nada mais fácil nem mais inútil do que refutar um filósofo}

Schopenhauer

"Tendências gerais da filosofia na segunda metade do século XIX", como já é sabido, foi dado a lume na Revista de Portugal, dirigida por Eça de Queirós, nos números referentes a Janeiro, Fevereiro e Março de 1890, ano do Ultimatum inglês e da efervescência política, social e cultural por ele suscitada.

E logo se impõe interrogar: quem é que, por então, pôde ler com os vagares e a necessária disponibilidade esse como que testamento espiritual do homem que, a partir da "Questão Coimbrã", fora como que uma das referências obrigatórias noevolver da consciência político-cultural portuguesa?

De certo, muito poucos o teriam logrado e isso por dois motivos: a Revista não contava com muitos leitores; e destes quantos dispunham da cultura e da atenção necessárias para manter, no decurso desses meses de tanta comoção pública, o interesse e a disponibilidade relativamente aum escrito que, não obstante a sua excepcional qualidade, além de difícil era ainda publicado em folhetins mensais?

Com efeito, só a partir de cerca de vinte anos depois da publicação 
é que principiaram as reacções culturais, significativas acerca da importância nacional desse escrito.

Assim, em 1909, António Sérgio estreia-se nas lides em que seria mestre com Notas sobre os "Sonetos" e as "Tendências Gerais da Filosofia" de Antero e ainda, nesse mesmo ano, Fidelino de Figueiredo dá a lume Antero de Quental. A sua Psicologia, a sua Filosofia e a sua Arte.

Um ano após, Jaime Cortesão publica a sua tese de licenciatura em Medicina, A Arte e a Medicina-Antero de Quental e Sousa Martins.

Em 1921, ou seja, cerca de trinta anos após a revelação do último escrito importante de Antero, Leonardo Coimbra tentaria, e com extraordinária penetração, o estudo de $O$ Pensamento Filosófico de Antero de Quental; três anos depois, António Sardinha procura entrever "O verdadeiro Antero" ( ${ }^{45}$ ); e em 1929, Joaquim de Carvalho dá a público a primeira versão de $A$ evolução Espiritual de Antero $\left({ }^{46}\right)$.

Ora, este livro do grande Mestre coimbrão seria impossível sem a tarefa a que, entretanto, metera ombros com Cândido Augusto Nazare: a publicação integral das Prosas anterianas, a qual decorreria de 1923 a 1931. Aí, pela primeira vez, e quarenta e um anos após a primeira impressão na Revista de Portugal, "Tendências gerais da filosofia na segunda metade do século XIX" passou a estar às mãos dos seus parcos virtuais leitores. Tardou, sem dúvida, mas chegou a tempo de permitir aos estudiosos do pensamento português um acesso fácil e de confiança a esse texto fundamental não só da lusa evolução cultural mas também, como é b́bvio, da do seu autor $\left({ }^{47}\right)$.

E eis que, volvido um século após a sua revelação, Ana Maria Almeida Martins encontrae estuda o original manuscrito de "Tendências gerais... " o que permite a sua primeira edição crítica, em vias de efectivação.

$\left({ }^{45}\right)$ In Ao Princípio Era o Verbo, Lisboa, 1924.

${ }^{(46)}$ Republicado muito acrescentado e modificado em Estudos sobre a Cultura Portuguesa do Século XIX vol. IAntheriana, Coimbra, 1955. Este estudo fundamental seria, por seu turno, recolhido em Obra Completa, vol. IV, pp. 545-695, Lisboa, Fundação Calouste Gulbenkian, 1983.

${ }^{\left({ }^{7}\right)}$ Permita-se-nos, neste ensejo, lamentar que a tarefa de levar a cabo a edição da Obra Completa de Antero de Quental, empreendida por António Salgado Júnior, se tenha ficado pelo primeiro volume, Prosas da Época de Coimbra, Lisboa, 1973. Realização modelar, insondáveis desígnios dos Deuses impediram que ela prosseguisse em virtude da doença e da morte do grande investigador que foi António Salgado Júnior. 
As "Tendências gerais... ", especialmente no seu terceiro capítulo, sugerem logo a hipótese de trabalho da sua provável relação com o fenómeno literário-cultural do romantismo tal como ele se desenvolvera não só na Europa mas também e porventura sobretudo em Portugal nas suas inter-conexões com os ritmos do devir da sociedade lusa $\left({ }^{48}\right)$.

E aí, e por aí, é fácil entrever e comprovar quer as relações subtilmente profundas, por um lado, entre Antero e Herculano e, por outro, entre Pascoaes e a essência da busca poético-filosófica anteriana.

Infelizmente, ocorre que "romantismo" é designação por de mais genérica e fluida para que, por aí, em nosso entender, seja possível vislumbrar a compreensão radical da génese e evolução do que caracterizara, iluminando-a, a caminhada do autor de Sonetos.

Aquilo que, neste ensejo, se pretende sugerir étão-só que "classificar" é pouco, e mesmo muito pouco, para uma aproximação efectiva da constelação de vivências, tantas vezes, em conflito que matizaram o percurso anteriano. $\mathrm{E}$ isso, especialmente, quando se tem em vista sobretudo a constelação filosófica ou para-filosófica do autor que se está a considerar. É que se houve uma filosofia que coincidiu, no tempo, com o devir do romantismo, e até influenciando-o, e, por seu turno, sendo influenciada por essa vaga histórica de teor estético-literário, tal filosofia obedecera, em última e essencial instância, a uma problemática própria e de acordo com raízes bem antigas, ou seja, afinal, de origens helénicas.

Com efeito, por mais romântica ou afim do romantismo possa ser considerada dada filosofia, a verdade é que esta, ao fim e ao cabo, radica, essencialmente, em problemas formulados e encaminhados mediante uma metodologia e um objecto próprios relativamente aos quais a estesia literária, ainda que possa estar presente, conta muito pouco ou, em última instância, talvez mesmo nada.

Ora, a formação cultural básica de Antero (e as suas necessárias metamorfoses) passa pelo seu ambiente familiar micaelense e, sobretudo, pela experiência coimbrã da qual constituem aspectos fundamentais os amigos e colegas universitários, as leituras levadas a

$\left({ }^{48}\right)$ V., de nossa autoria, "O devir da poesia romântica no devir da sociedade burguesa (Esboço de investigação" in Temas de Cultura Portuguesa, Lisboa, 1983. 
efeito, o descobrimento de grandes autores de além-fronteiras - e o bacharelato em Direito, aliás, com a classificação nemine discrepante. $\mathrm{E}$, a este último respeito, por mais que, após vinte e três anos sobre a sua formatura coimbrã, ele tenha confidenciado a Wilhelm Storck "que não foi o estudo do Direito que me interessou e absorveu durante aqueles anos, tendo sido e ficado um insignificante legista" $\left({ }^{49}\right)$, afigura-se legítimo considerar-se que tal experiência lhe não fora nem tão despicienda nem tão inútil como sugere.

Com efeito, se Antero jamais se encarreirou por qualquer das pistas profissionais que a formatura coimbrã lhe abria, isso acontecera, antes de mais, porque os seus bens familiares e respectivos rendimentos the permitiam e permitiriam o "luxo" e a liberdade de recusar qualquer actividade que não fosse a de procurar encontrar-se a si próprio num projecto exaltante de vida, o que, aliás, jamais aconteceria de modo pleno.

Ora, nessa busca e, pelo menos, em algumas das suas metamorfoses sobretudo as de carácter sociopolítico, é claro que a sua formação de jurista (considerada lato sensu) está implícita e até explícita no seu afã de pensar e de repensar e de procurar viver uma nova e futurante definição de justiça social. E daí, como lembra, o ter descido "confiado para a arena: queria reformar tudo, eu que nem sequer estava ainda a meio caminho da formação de mim mesmo! Consumi muita actividade e algum talento, merecedor de melhor emprego, em artigos de jornais, em folhetos, em proclamações, em conferências revolucionárias: ao mesmo tempo que conspirava a favor da União Ibérica, fundava com a outra mão sociedades operárias e introduzia, adepto de Marx e Engls, em Portugal a Associação Internacional dos Trabalhadores. Fui durante uns 7 ou 8 anos uma espécie de pequeno Lassale, e tive a minha hora de vã popularidade" $\left({ }^{50}\right)$.

Pois bem! Como em mais de um ensejo temos sugerido, há efectiva relação entre o fracasso mortal do Programa para os Trabalhos da Geração Nova (1871-75), no qual, de corpo e alma, se embrenhara, e a origem da busca efectiva de uma filosofia tão autónoma quanto lhe fosse sendo possível $\left.{ }^{(51}\right)$. Pretende-se insinuar o seguinte: por aí e por

\footnotetext{
$\left({ }^{49}\right)$ Cartas II (1881-1891). Organização, introdução e notas de Ana Maria Almeida Martins, Lisboa, 1989, p. 833.

$\left.{ }^{(50}\right)$ Idem, ibidem, p. 834. Itálicos nossos.

(51) V., de nossa autoria, Antero e a Ruína do seu "Programa", Lisboa, 1988.
} 


\section{O último escrito filosófico de Antero de Quental}

esse modo, é que Antero pretendeu entreabrir vias adequadas para o equacionamento dos problemas que se lhe foram deparando e tornando-se cada vez mais complexos.

$\mathrm{O}$ "discipulato" de Marx e Engls, assumido em 1871-1872 $\left({ }^{52}\right)$, encaminhar-se-ia, rapidamente, para uma via de teor cada vez mais proudhoniano e mais de acordo com a evolução das vivências que seriam, a seu tempo, as da "sua" filosofia à qual, vagorosa e sinuosamente, ia aportando.

Assim, a partir de 1880, pronuncia-se sistematicamente no sentido de que o socialismo não teria sentido algum quando desprovido da sua matriz e fins essencialmente éticos. "Cegos! que não compreendem que as coisas da consciência não se pesam na grosseira balança das coisas materiais, que é a qualidade aqui e não o número que faz o valor, e que uma só consciência recta e sã vale incomparavelmente mais do que milhares, ou milhões que fossem, de consciências turvas, cobardes e envilecidas" $\left({ }^{53}\right)$.

Pouco depois, proclamaria: "O princípio falso do egoísmo preside por toda a parte às relações sociais dos homens, em vez do santo princípio da fraternidade; e o mundo, em vez de nos apresentar o espectáculo consolador de uma só família de irmãos, apresenta-nos o quadro cruel de um vasto e confuso campo de batalha, onde cada homem é um combatente, que só procura engrandecer-se com os despojos daqueles que devia considerar como irmãos!" $\left({ }^{54}\right)$

Em 1885, em "Socialismo e filantropia", discreteia por este modo: "Quem diz Filantropia diz, ainda que o não queira, socialismo e igualdade: jura por uma divindade encoberta, divindade que não conheceram nossos avós, e em cujas aras têm de arder pelo holocausto muitas cousas que respeitaram e ate veneraram nossos pais" $\left({ }^{55}\right)$.

Ora, no princípio do ano em que redigira "Tendências gerais... ", Antero pronuncia-se sobre o socialismo e a moral. E o que aí afirma, com um alor novo, é, essencialmente, o seguinte: "A emancipação dos trabalhadores deve ser obra dos mesmos trabalhadores. Neste lema da primitiva Associação Internacional dos Trabalhadores encerra-se uma

$\left.{ }^{(52}\right)$ V. Antero de Quental, Prosas Sociopolíticas. Publicadas e apresentadas por Joel Serrão, Lisboa, 1982, pp. 327-394.

$\left({ }^{53}\right)$ Idem, ibidem, p. 433.

( ${ }^{\text {S4 }}$ Idem, ibidem, p. 436. Datado de 1881.

(55) Idem, ibidem, p. 439. 
verdade fundamental, e mais compreensiva ainda do que, porventura, pensavam os que a redigiram, homens de luta e exclusivamente políticos. (...) por conseguinte, antes de tudo e como primeira condição, da sua energia moral, da sua perseverança, da sua firme dignidade, numa palavra, não somente da agitação colectiva, muitas vezes superficial e inconsistente, mas da sólida virtude dos indivíduos. Cousa alguma grande e duradoura se fundou ainda no mundo senão pela moral: $e$, se o Socialismo tem de ser uma esplêndida realidade, só o será como um passo mais no caminho da evolução moral das sociedades" ${ }^{(56)}$.

Se se acerta no alvo, aquilo de que aí se trata é de uma como que adunação entre a experiência sociopolítica, cujas raízes provinham de 1871, e a busca especificamente filosofica que, sobretudo, a partir de 1875 , o filosofo-aprendiz procurava soerguer das contradições, dos hiatos e das sombras que o impediam de divisar e de equacionar, mesmo que tão-só por via cautelosamente indutiva $\left({ }^{57}\right)$, os subtis e movediços nexos entre o Ser e o Bem ou, se se preferir, entre o Bem e o Ser.

Num dos seus mais belos escritos, "Um génio que era um santo" (1896), Eça de Queirós, ao fim e ao cabo, "responsável" pela redacção e publicação de "Tendências gerais... " legou-nos um testemunho da maior importância sobre o contexto da procura filosófica anteriana.

"Passaram anos em que não vi Antero, instalado então em Vila do Conde. Sabia que o meu amigo estava quase são, quase sereno. Mas foi uma preciosa surpresa, quando, ao fim dessa separação, chegando ao Porto e correndo com Oliveira Martins a Vila do Conde, avistei na estação um Antero gordo, róseo, reflorido, com as lapelas do casaco de alpaca atiradas para trás galhardamente e meneando na mão a grossa bengala da Índia que em Lisboa eu lhe dera para amparar a tristeza e a fadiga. (...) Era sobretudo uma ressurreição moral, à velha maneira de Lázaro, uma miraculosa saída do túmulo pessimista e das sombras da negação. Findara a luta implacável, o seu grande coração, enfim,

\footnotetext{
${ }^{(56)}$ Idem, ibidem, p. 441.

( $\left.{ }^{57}\right)$ Fernando Catroga, "Metafísica Indutiva de Antero de Quental", Biblos, Coimbra, vol. LXI, 1985.
} 
descansava em paz!

Como chegara Antero a esse repouso apetecido? Escutando com uma atenção mais grave, mais crente, aquela voz da Consciência, que tanto tempo desconhecera, e apesar de todos os desenganos e sempre em segredo protesta e afirma o Bem.

Fora atendendo reverentemente essa doce voz; e conseguindo, por um desesperado esforço do pensamento, penetrar a sua significação; e refazendo, guiado por ela, a sua educação filosófica; e procurando depois a sua confirmação na história, nas doutrinas dos moralistas, nas confissões dos místicos, que ele chegara a descobrir, a compreender bem o fim último e verdadeiro de tudo, não só do homem moral, mas de toda a Natureza, mesmo na sua modalidade física. E essa descoberta é de inefável beleza e contentamento - pois que o fim de tudo é o Bem! O Universo tem por fim o Supremo Bem - o Bem é o momento final e augusto de toda a evolução do Universo.

Possuía pois Antero, enfim, a 'sua filosofia', essa filosofia que ele tantos anos perseguira como deusa esquiva entre selvas duvidosas, e que fora sempre para os seus amigos, alternadamente, motivo de esperança, de desconfiança, de entusiasmo e de sarcasmo... Mas agora Antero alcançara a deusa esquiva. E a lei moral dessa filosofia (de que ele deu na 'Revista de Portugal' um esboço eloquente e poético) consistia em renunciar a tudo quanto limita e escraviza o espírito egoísmo, paixões, vaidades, ambições, contingências, materialidades do mundo, - e em procurar a união do espírito, assim libertado e limpo de todo o pesado lodo terreno, com o seu tipo de perfeição que usualmente se chama 'Deus'. Essa união, em que a vontade limitada se dissolve na vontade absoluta, será tanto mais eficaz quanto mais completa for a renúncia a tudo o que é egoísta, particular, individual. E só pela união com o Ser perfeito, de que essa renúncia é instrumento e condição, se realiza o Bem, o Bem supremo, fim verdadeiro de toda a vida, fim divino a que tende o Universo. Em resumo, a lei moral do homem é o constante aperfeiçoamento e a progressiva santidade" ${ }^{58}$ ).

Nas suas linhas fundamentais, o testemunho de Eça de Queirós é exacto e confirmável por tudo quanto, hoje, se vai sabendo sobre a

$\left({ }^{(8)}\right)$ Notas Contemporâneas, fixação do texto e notas de Helena Cidade Moura, Lisboa, s. d., pp. 273-274. 
elaboração da filosofia anteriana nos cerca de dez anos decorridos desde 1875 e 1885 .

Por 1875, fora a destruição do Programa para os Trabalhos da Geração Nova e "aquilo" que lhe restara em termos de problemas a reequacionar; em data incerta mas anterior a 1885 , os apontamentos de revelação póstuma sob o título de "Ensaio sobre as bases filosóficas da Moral ou Filosofia da Liberdade" $\left({ }^{59}\right)$; em 1886, "A filosofia da natureza dos naturalistas" $\left({ }^{60}\right)$ escrito inseparável da "Tendências Gerais... ", com o qual, então, Antero nem sonharia.

Com efeito, a crítica ao coevo materialismo mecanicista, do qual Haeckel (1834-1919) fora e era o expoente mais significativo, implica a "certeza" de que Antero estava, por então, na posse de um conjunto de filosofemas aos quais Eça chamaria, e com razão, a "sua filosofia". É que essa crítica à atitude e sistematização materialistas, embora publicada num jornal, eescrita, como parece num jacto de extraordinária e perspicaz eloquência, pressupõe um conjunto de realidades que importa explicitar.

A primeira traduz-se no exercício da peculiar eloquência de Antero como polemista, ou seja, quando situado ante a necessidade de contestar o que considera uma inverdade ou meia verdade, relativamente a assunto que julga conhecer bem. Ora, a inverdade de outrem implica a "verdade" à qual haveria aportado após anos de porfia.

A segunda realidade que se entrevê consiste na quase certeza a que se é levado de que esse escrito só se tornara possível porque, antes da data em que ele viria a ser redigido, Antero havia rematado a sua procura filosófica, ou, por outras palavras, entrevira, enfim, o seu "sistema", o que remete, novamente, para a data de cerca de 1885.

Nestes termos, afigura-se-nos como inteiramente plausível a necessidade de considerar-se "A filosofia da natureza dos naturalistas" inseparável de "Tendências gerais... " embora isso não tenha resultado de qualquer plano prévio do autor. Tal como, afinal, "Tendências gerais... ", a seu tempo, também não resultaria de qualquer plano previamente estabelecido mas da contingência de um convite para escrever um artigo para uma revista dirigida por um amigo...

$\left(^{59}\right)$ V. esse texto e os respectivos comentários em Antero de Quental, Obras Completas, Filosofia, Lisboa, 1991.

$\left({ }^{60}\right)$ Idem, ibidem. 
Assim, se os dois últimos escritos filosóficos de Antero não podem ou não devem ser considerados isoladamente, isso não significa, todavia, que eles sejam partes de um todo que, como tal, jamais foi explicitado - a filosofia de Antero. E o mais frustrante, em tudo isso, é que ele estava a caminho de tê-la!

E uma interrogação se nos impõe, embora logo à partida, ela se nos apresente de extrema complexidade por óbvias razões de historicidade. É a seguinte: em última instância, teria sido Antero um filosofo de compieição "socrática", muito mais interessado em suscitar problemas do que em sistematizar as respostas que para eles ia entrevendo? E, nessa perspectiva, poderá sugerir-se que as suas cartas pessoais e os seus panfletos ou artigos preencheram, no contexto da sociedade portuguesa do século XIX, uma função que se diria homóloga daquela que Sócrates assumira na Grécia do século V a. C.?

Sinceramente, não sabemos se é possível responder, ou sequer procurar responder a tais interrogações. Mas algo, a esse respeito, se nos afigura como certeiro: as suas falas epistolares conhecidas assumem, e cada vez mais, uma importância cimeira no conhecimento do seu pensamento; e os folhetos e artigos que fora lançando a público desencadearam conflituais problemas como os da dignidade e liberdade do escritor, da procura da via socialista para o equacionamento dos problemas sociopolíticos da contemporaneidade, da via do futuro de Portugal, etc.; e no que toca à evolução da cultura portuguesa dos fins do século XIX até aos meados desta nossa centúria, quem é que ignora a presença difusa ou infusa da sua "filosofia", embora, como tal, ela não tenha chegado a ser sistematizada?

Perdoai a vereda "socrática" pela qual não desejamos internarmo-nos mais, e retorne-se às "Tendências gerais... ", razão deste bem sinuoso escrito.

Não se alimentam grandes dúvidas sobre os problemas fundamentais dos dois últimos escritos filosóficos anterianos. Tais problemas são: 1) o da interdependência entre ciência e filosofia não obstante as suas metodologias próprias condicionadas por objectos específicos, o que, logo à partida, elimina a viabilidade, e, sobretudo, a validade de toda e qualquer especulação de teor positivista ou para-positivista; 2) a natureza e o espírito são realidades próprias e específicas, o que frustra, por óbvias razões, qualquer compromisso ontológico entre elas; 3) e daí que o conceito leibniziano de mónada tenha sido a 
"solução" encontrada para que, afinal, o espiritualismo anteriano pudesse alcançar o seu estatuto próprio e buscar a sua via de autónomo desenvolvimento.

"Porque é que este mundo em que existimos e de que fazemos parte, este mundo que somos, sendo o único mundo que existe para nós, o único real, o único possível, o único concebível, é ao mesmo tempo um mundo que não tem em si nem a sua causa, nem a sua razão de ser, nem a sua substancialidade - que não tem em si a sua verdadeira existência? Existe, porventura, uma unidade suprema em que se fundam e desapareçam estes dois elementos antitéticos e ao parecer irredutíveis da ideia do Ser e que os deixe por essa síntese, reduzidos a simples momento? e qual é essa unidade? e qual a razão dessa aparente oposição dentro da unidade superior?"

Assim se interrogava Antero para logo insinuar: "É bem sabido que ainda não foi possível à Filosofia dar a estas perguntas uma resposta que satisfaça - quer seja por que a nossa razão limitada não chega a penetrar na região onde tal problema achará solução, ou por que efectivamente o problema em si não existe e é apenas um resultado da constituição particular do nosso entendimento" $\left.{ }^{61}\right)$.

E voltando a interrogar-se, Antero escreve: "por que não tomaremos outro caminho? por que não aceitaremos esta antinomia, como o dado primeiro da razão, o ponto preciso em que (seja pelo que for) o real e o ideal se tocam sem se confundirem, e não tentaremos construir sobre ele, como sobre a rocha primitiva, o edifício das nossas especulações? Seja por que motivo for, esta antinomia é, se não o facto em si, com certeza o nosso facto, o facto evidente da nossa mesma constituição. Ela é, ao menos para nós, o incognoscível, e só para cá desse incognoscível é que a Filosofia pode começar. Sendo assim, so aí deve começar" $\left({ }^{62}\right)$.

E revertendo à interrogação, o nosso filósofo "secreto" questiona: "O que éo Absoluto? O que é a Realidade? Em que relação estão, como se comportam um para com o outro estes dois elementos do Ser? Qual é, em vista dessa relação, a razão necessária que preside ao Universo? Qual é, por conseguinte, a essência mesma do Universo? E, dado o

$\left({ }^{61}\right)$ "Ensaio sobre as bases filosóficas da Moral ou Filosofia da Liberdade" in Antero de Quental, Obras Completas, Filosofia, Lisboa, 1991.

$\left({ }^{62}\right)$ Idem, ibidem. 
conhecimento dessa essência, o que devemos pensar da natureza e do seu curso, do Espírito e das suas tendências, da Humanidade e da sua História? Qual é a Causa? Qual é o Fim? Qual o Processo?" ( $\left.{ }^{63}\right)$.

Interrogar bem faz parte da "viagem" filosófica pois que outra bússola não há para tais percursos, - e isso desde os Gregos.

Mais: a interrogação adequada e pertinente só possível ao aprendiz de filósofo quando, enfim, se lhe entreabre a via da indagação efectiva. Éque interrogaçãoe problematização constituem um todo indissociável. E nenhuma filosofia, como tal, é válida se não for a tentativa de equacionamento de um problema formulado com pertinência.

Ora, se se acerta no alvo, quer "A filosofia da natureza dos naturalistas" quer "Tendências gerais da filosofia na segunda metade do século XIX" são respostas, ou melhor, esboços de resposta, porque, conjunturalmente, apressadas a problemas longamente congeminados.

E daí que, mesmo o mais longo e o mais importante dos ensaios filosoficos anterianos padeça dos circunstancialismos da sua escrita, como, aliás, se principiou por mostrar.

Em suma de suma: Antero não logrou expor, em termos "canónicos", a filosofia a que aportara depois de tão agitada e dramática "viagem" da qual tão-só nos restaram alguns indícios do oiro que a morte, enigmática e avarentemente, levou consigo - e para sempre.

${ }^{(63)}$ Idem, ibidem. 